Article

\title{
Methane and Hydrogen Sulfide Production from Co-Digestion of Gummy Waste with a Food Waste, Grease Waste, and Dairy Manure Mixture
}

\author{
Abhinav Choudhury and Stephanie Lansing *(1) \\ Department of Environmental Science and Technology, University of Maryland, University of Maryland Energy \\ Research Center, 1429 Animal Science/Ag Engineering Bldg., College Park, MD 20742, USA; \\ abhinavc@terpmail.umd.edu \\ * Correspondence: slansing@umd.edu; Tel.: +1-(301)-405-1197
}

Received: 1 November 2019; Accepted: 19 November 2019; Published: 23 November 2019

check for updates

\begin{abstract}
Co-digestion of dairy manure with waste organic substrates has been shown to increase the methane $\left(\mathrm{CH}_{4}\right)$ yield of farm-scale anaerobic digestion (AD). A gummy vitamin waste (GVW) product was evaluated as an AD co-digestion substrate using batch AD testing. The GVW product was added at four inclusion levels $(0 \%, 5 \%, 9 \%$, and $23 \%$ on a wet mass basis) to a co-digestion substrate mixture of dairy manure (DM), food-waste (FW), and grease-waste (GW) and compared to mono-digestion of the GVW, DM, FW, and GW substrates. All GVW co-digestion treatments significantly increased $\mathrm{CH}_{4}$ yield by $126-151 \%$ (336-374 $\mathrm{mL} \mathrm{CH}_{4} / \mathrm{g}$ volatile solids (VS)) compared to DM-only treatment (149 $\mathrm{mL} \mathrm{CH}_{4} / \mathrm{g} \mathrm{VS}$ ). The GVW co-digestion treatments also significantly decreased the hydrogen sulfide $\left(\mathrm{H}_{2} \mathrm{~S}\right)$ content in the biogas by $66-83 \%\left(35.1-71.9 \mathrm{~mL} \mathrm{H}_{2} \mathrm{~S} / \mathrm{kg} \mathrm{VS}\right)$ compared to DM-only ( $212 \mathrm{~mL} \mathrm{H}_{2} \mathrm{~S} / \mathrm{kg}$ VS) due to the low sulfur (S) content in GVW waste. The study showed that GVW is a potentially valuable co-digestion substrate for dairy manure. The high density of VS and low moisture and $\mathrm{S}$ content of GVW resulted in higher $\mathrm{CH}_{4}$ yields and lower $\mathrm{H}_{2} \mathrm{~S}$ concentrations, which could be economically beneficial for dairy farmers.
\end{abstract}

Keywords: biochemical methane potential; biogas; anaerobic digestion

\section{Introduction}

Anaerobic digestion (AD) of organic substrates with dairy manure, also known as co-digestion, can increase biogas production and result in higher return on investment for dairy farmers [1]. Biogas produced from AD is a combination of $50-75 \%$ methane $\left(\mathrm{CH}_{4}\right)$ and $25-50 \%$ carbon dioxide $\left(\mathrm{CO}_{2}\right)$, with trace levels $(0.01-1 \%)$ of hydrogen sulfide $\left(\mathrm{H}_{2} \mathrm{~S}\right)$ that can be used as a source of renewable energy for heat and power generation [2]. Limitations from mono-digestion of organic materials arise from substrate properties, such as unbalanced C:N ratios, recalcitrance in the feedstock, high concentrations of long chain fatty acids, and deficiency in trace minerals required for the growth of methanogens $[1,3]$. These limitations can lead to unfavorable economics for dairy farmers using AD to generate energy on-farm [1,4]. Furthermore, positive synergy from co-digestion of a mixture of substrates can lead to more $\mathrm{CH}_{4}$ production than the addition of $\mathrm{CH}_{4}$ produced from mono-digestion of each individual substrate. A review by Mata-Alvarez et al. (2014) reported that co-digestion of carbon (C)-rich organic matter with cattle and poultry manure resulted in up to 3.5 times more $\mathrm{CH}_{4}$ production than the $\mathrm{CH}_{4}$ potential of the individual substrates [3]. Lisboa and Lansing (2013) reported a maximum of 29.4 times more $\mathrm{CH}_{4}$ yield when dairy manure was co-digested with chicken processing waste compared to mono-digestion of dairy manure [5]. Moody et al. (2011) determined the biomethane potential of a wide range of food waste substrates and concluded that co-digestion of manure and 
organic waste has the potential to increase biogas production, and in turn, increase energy generation from AD [6]. However, often studies are only applied to individual substrates due to differences in organic waste composition and collection.

Previous research on co-digestion of food waste and dairy manure has primarily focused on the $\mathrm{CH}_{4}$ production potential of co-substrates [7-9], with limited data on the effects of co-digestion substrate selection on the production of $\mathrm{H}_{2} \mathrm{~S}$ [10]. The production $\mathrm{H}_{2} \mathrm{~S}$ in biogas occurs when sulfur-containing compounds, such as sulfates, sulfites, and thiosulfate, in AD substrates are reduced by sulfate-reducing bacteria (SRB) under anaerobic conditions [11]. High $\mathrm{H}_{2} \mathrm{~S}$ concentrations in biogas $(0.05-1 \%$ by vol.) can become a major problem when utilizing the biogas due to health concerns and corrosion of biogas equipment [12]. Combined heat and power (CHP) systems usually require $\mathrm{H}_{2} \mathrm{~S}$ concentrations to not exceed $500 \mathrm{ppm}$ to prevent reduced performance from corrosion, and $\mathrm{H}_{2} \mathrm{~S}$ concentrations over $100 \mathrm{ppm}$ can lead to severe adverse human health impacts [10]. Most dairy farms use CHP systems to generate energy for on-farm use and lower $\mathrm{H}_{2} \mathrm{~S}$ concentrations can lead to improved energy generation efficiencies and reduced maintenance. Corro et al. (2013) observed a reduction in $\mathrm{H}_{2} \mathrm{~S}$ concentrations when coffee waste was co-digested with dairy manure compared to digestion of dairy manure only, but there was no discussion of the cause for the observed $\mathrm{H}_{2} \mathrm{~S}$ differences [13]. Research has shown that co-digestion of organic matter with higher $\mathrm{C}: \mathrm{N}$ ratios in manure-based digesters can reduce ammonia inhibition and enhance methane production [3]. Co-digestion of carbon-rich organic matter with a low sulfur (S) content may also reduce the $\mathrm{H}_{2} \mathrm{~S}$ concentration in the biogas when compared to the mono-digestion of dairy manure and prevent sulfide inhibition.

Industrial food waste comprises $5 \%$ of the total food waste generated globally [14]. Although the fraction of industrial food waste is significantly less than food waste from other sources, it has logistical and economic advantages due to its high-volume generation at specific points and homogenous nature. Valorization of these industrial food waste streams can help mitigate disposal costs in landfills, while providing a source of tipping fees for dairy farmers with AD systems. The waste produced from gummy vitamin industries is high in degradable $C$ compared to dairy manure. Production of gummy vitamin waste (GVW) from a single manufacturing facility can be up to $10 \%$ of the total weight of the product produced [15]. For example, one multi-national gummy vitamin manufacturing company produces approximately 100 million gummy vitamins daily, with a daily production of 500 tons of gummy product ( $5 \mathrm{~g}$ per gummy vitamin), resulting in approximately 50 tons/day of GVW produced [16]. Most of this waste product is landfilled, with some composting and incineration being practiced in the EU $[15,17]$. The GVW material can contain up to $70 \%$ sugar and gelatin, with starch or pectin-based gels that create the unique structure that is characteristic of gummy candies [18]. Due to its high sugar content, GVW can be a valuable resource for AD, yet the dense jelly-like consistency may lead to issues, such as a slow degradation rate, increased hydraulic retention time, or possible pipe clogging within the AD system. It is also possible that GVW with a high C:S ratio could reduce the $\mathrm{H}_{2} \mathrm{~S}$ concentration in the biogas when co-digested with dairy manure.

The main goal of the project was to evaluate a GVW product as a co-digestion substrate for $\mathrm{AD}$. The specific objective was to evaluate the $\mathrm{CH}_{4}$ and $\mathrm{H}_{2} \mathrm{~S}$ production and VS degradation of a GVW substrate when co-digested with a dairy manure (DM), food waste (FW), and grease waste (GW) mixtures (DM.FW.GW). A co-digestion mixture was used for testing, as many on-farm digesters incorporate multiple waste streams and to highlight the benefits of testing co-substrates as both mixtures and single substrates. Co-digestion of the tested mixtures was expected to produce a significantly higher amount of $\mathrm{CH}_{4}$ and lower $\mathrm{H}_{2} \mathrm{~S}$ compared to the mono-digestion of DM.

\section{Materials and Methods}

\subsection{Sample Collection}

Anaerobic digester effluent (inoculum source) and the GVW product were collected from a Northeastern US farm. The farm co-digested dairy manure from heifers with gummy vitamin waste, 
food waste, and grease waste at a $64 \% \mathrm{DM}, 9 \% \mathrm{GVW}, 16 \% \mathrm{FW}$, and $11 \% \mathrm{GW}$ ratio, by mass. The AD effluent sample was utilized as an inoculum source, as it had been pre-acclimated to the GVW material used at the farm. The GW and FW were collected from a local supermarket. Un-separated dairy manure from the USDA Beltsville Agricultural Research Center (BARC) in Beltsville, MD, USA, was utilized as the DM substrate. Field samples were collected and brought back to lab on ice. The mean total solids (TS) and volatile solids (VS) data for the substrates used in the experiment are shown in Table 1.

Table 1. Total and volatile solids content of the individual substrates (gummy vitamin waste, food waste, grease waste, dairy manure) and digester effluent (inoculum) used for the experiment.

\begin{tabular}{cccccc}
\hline Parameters & $\begin{array}{c}\text { Gummy } \\
\text { Vitamin Waste }\end{array}$ & Food Waste & Grease Waste & Dairy Manure & Inoculum \\
\hline Total Solids (g/kg) & $464 \pm 2.0$ & $91.0 \pm 1.0$ & $673 \pm 4.5$ & $94.5 \pm 3.6$ & $64.8 \pm 0.9$ \\
Volatile Solids (g/kg) & $463 \pm 2.1$ & $83.1 \pm 1.1$ & $645 \pm 1.5$ & $81.7 \pm 3.6$ & $47.5 \pm 0.8$ \\
\hline
\end{tabular}

\subsection{Experimental Design}

The GVW product was added to individual batch digesters at four inclusion levels $(0 \%, 5 \%, 9 \%$, and $23 \%$ on a wet mass basis) to a co-digestion substrate mixture of dairy manure (DM), food-waste (FW), and grease-waste (GW) and compared to mono-digestion of the GVW, DM, FW, and GW substrates, with an inoculum control. The 9\% GVW treatment (64\% DM, 16\% FW, 11\% GW by mass) represented the mixture that was used at the farm during the time of AD effluent collection. An inoculum-to-substrate ratio (ISR) of 1:1 (VS basis) was used for the experiment. Table 2 shows the experimental design and the descriptions of the treatment levels for the experiment, with each treatment conducted using triplicate $\mathrm{AD}$ reactors. All mass data are expressed on a wet mass basis.

Table 2. Experimental design using a 1:1 inoculum-to-substrate ratio, with the calculated initial total solids (TS) and volatile solids (VS) of the treatment mixtures. The percent of gummy vitamin waste (GVW) inclusion was based on mass. All treatments were conducted in triplicate.

\begin{tabular}{|c|c|c|c|c|c|c|c|}
\hline $\begin{array}{l}\text { Digestion Substrate } \\
\text { and Inoculum }\end{array}$ & Inoculum (g) & DM (g) & FW (g) & GW (g) & GVW (g) & TS $(g / L)$ & VS $(g / L)$ \\
\hline Inoculum control & 31.9 & - & - & - & - & 64.1 & 47.0 \\
\hline Food waste (FW) & 31.9 & - & 18.1 & - & - & 74.2 & 60.0 \\
\hline Grease waste (GW) & 31.9 & - & - & 2.3 & - & 105 & 87.6 \\
\hline Gummy vitamin waste (GVW) & 31.9 & - & - & - & 3.2 & 101 & 85.5 \\
\hline GVW.DM.FW.GW (9\% GVW) & 31.9 & 5.2 & 1.4 & 0.9 & 0.8 & 89.5 & 74.5 \\
\hline GVW.DM.FW.GW (23\% GVW) & 47.9 & 5.2 & 1.4 & 0.9 & 2.4 & 93.1 & 78.0 \\
\hline
\end{tabular}

\subsection{Biochemical Methane Potential (BMP) Test Procedures}

The batch laboratory testing followed the biochemical methane potential (BMP) protocol, which is a laboratory batch study used to characterize $\mathrm{CH}_{4}$ production potential [6]. Substrate and inoculum were added into $300 \mathrm{~mL}$ serum bottles, purged with $\mathrm{N}_{2}$ gas to establish anaerobic conditions, capped, and incubated at $35^{\circ} \mathrm{C}$ in an environmental chamber. Biogas, $\mathrm{CH}_{4}$, and $\mathrm{H}_{2} \mathrm{~S}$ concentrations were monitored at regular intervals for 67 days, at which point the daily biogas production was less than $1 \%$ of the cumulative biogas production for the treatments, indicating biogas production had largely ceased. The mass of substrate and inoculum in each bottle ranged from 31.4 to $58.8 \mathrm{~g}$ (Table 2) to keep the ISR at 1:1 for all treatments.

The quantity of biogas produced was measured using a graduated, gas-tight, wet-tipped $50 \mathrm{~mL}$ glass syringe inserted through the septa of the digestion reactors and equilibrated to atmospheric pressure. Biogas samples were collected in $0.5 \mathrm{~mL}$ syringes and tested on a gas chromatograph (Agilent 7890) using a thermal conductivity detector (TCD) at a detector temperature of $250{ }^{\circ} \mathrm{C}$ for $\mathrm{CH}_{4}$ 
and $\mathrm{H}_{2} \mathrm{~S}$ concentrations. The average $\mathrm{CH}_{4}$ and $\mathrm{H}_{2} \mathrm{~S}$ production in the triplicates from the inoculum control was subtracted from the other treatments to present the total $\mathrm{CH}_{4}$ production from the waste substrates only.

\subsection{Analytical Methods}

The treatment mixtures were analyzed for $\mathrm{pH}$ before and after digestion using an Accumet AB15 $\mathrm{pH}$ meter. Triplicate samples were tested for TS and VS, according to Standard Methods for the Examination of Water and Wastewater (APHA-AWWA-WEF, 2005) within $24 \mathrm{~h}$ of collection. For TS analysis, triplicate $10.0 \mathrm{~mL}$ samples were pipetted into pre-weighed porcelain crucibles. The samples were then dried at $105{ }^{\circ} \mathrm{C}$ until a constant mass was obtained for the TS concentration. The crucibles were then placed in a furnace at $550{ }^{\circ} \mathrm{C}$ until a constant weight was obtained to determine VS concentration. The gummy waste, dairy manure, and inoculum (digester effluent) were tested for total metals (iron, zinc) and sulfur using ICP-MS (inductively coupled plasma mass spectrometry), and total nitrogen using A3769 Methods for Manure Analysis at Agrolabs Inc., Harrington, DE, USA, [19]. The C:N ratio was calculated using the conversion factor from Adams et al. (1951) stating that $55 \%$ of the VS content is carbon [20]. The calculated C value and the measured $N$ value were used to derive the $\mathrm{C}: \mathrm{N}$ ratio.

\subsection{Statistical Analysis}

Collected data were reviewed in accordance with QA/QC procedures and analyzed for significant differences in biogas quantity, $\mathrm{CH}_{4}, \mathrm{H}_{2} \mathrm{~S}$, TS, VS, and $\mathrm{pH}$ using ANOVA and Tukey-Kramer post-hoc multiple mean comparison tests of the reviewed data using SAS ${ }^{\circledR}$ statistical software package. Tests of significance were conducted with an alpha value set at 0.05 . Data are reported as averages with standard errors (SE).

\section{Results}

\subsection{Methane $\left(\mathrm{CH}_{4}\right)$ Production}

The co-digestion mixtures 0-23\% GVW.DM.FW.GW had a significantly higher percent $\mathrm{CH}_{4}$ in the biogas compared to the mono-DM digestion ( $p$-value $<0.0001$; Table 3). However, there were no significant differences in the percent $\mathrm{CH}_{4}$ among the co-digestion mixtures, with a non-significant trend in increasing percent $\mathrm{CH}_{4}$ as the percent of GVW increased (Table 3). The cumulative $\mathrm{CH}_{4}$ production over the 67 day AD period was normalized using two methods: (1) the total mass of the substrate added ( $\mathrm{mL} \mathrm{CH}_{4} / \mathrm{g}$ substrate), as this normalization provides an estimate of $\mathrm{CH}_{4}$ production that can be readily used by farmers, and (2) the VS of the substrate $\left(\mathrm{mL} \mathrm{CH}_{4} / \mathrm{g}\right.$ VS added) for comparison with other studies [5].

Table 3. Methane $\left(\mathrm{CH}_{4}\right)$ and hydrogen sulfide $\left(\mathrm{H}_{2} \mathrm{~S}\right)$ production data from the batch digestion testing.

\begin{tabular}{|c|c|c|c|c|c|}
\hline Treatment & $\mathrm{CH}_{4}(\%) *$ & $\mathrm{~mL} \mathrm{CH}_{4} / \mathrm{g}$ VS & $\begin{array}{c}\mathrm{mL} \mathrm{CH}_{4} / \mathrm{g} \\
\text { Substrate }\end{array}$ & $\mathrm{mL} \mathrm{H}_{2} \mathrm{~S} / \mathrm{kg} \mathrm{VS}$ & $\begin{array}{c}\mathrm{mL} \mathrm{H}_{2} \mathrm{~S} / \mathrm{kg} \\
\text { Substrate }\end{array}$ \\
\hline Dairy manure (DM) & $53.7 \pm 0.5$ & $149 \pm 11$ & $12.2 \pm 0.1$ & $212 \pm 17$ & $17.4 \pm 1.4$ \\
\hline Food waste (FW) & $14.8 \pm 1.1$ & $0^{\#}$ & $0^{\#}$ & $99.7 \pm 8.8$ & $8.3 \pm 0.7$ \\
\hline Grease waste (GW) & $25.7 \pm 3.0$ & $10 \pm 4.5$ & $6.3 \pm 2.9$ & $33.1 \pm 30.4$ & $21.4 \pm 19.6$ \\
\hline Gummy vitamin waste (GVW) & $6.98 \pm 0.9$ & $0^{\#}$ & $0^{\#}$ & $7.0 \pm 0.1$ & $3.2 \pm 0.1$ \\
\hline DM.FW.GW (0\% GVW) & $67.4 \pm 0.2$ & $373 \pm 6$ & $56.0 \pm 0.8$ & $35.1 \pm 2.2$ & $5.3 \pm 0.3$ \\
\hline GVW.DM.FW.GW (5\% GVW) & $66.6 \pm 1.6$ & $374 \pm 12$ & $62.5 \pm 2$ & $71.9 \pm 13.7$ & $12.0 \pm 2.3$ \\
\hline GVW.DM.FW.GW (9\% GVW) & $68.3 \pm 1.2$ & $355 \pm 3$ & $64.1 \pm 0.5$ & $70.4 \pm 5.2$ & $12.7 \pm 0.9$ \\
\hline GVW.DM.FW.GW (23\% GVW) & $71.1 \pm 1.0$ & $336 \pm 12$ & $76.3 \pm 2.7$ & $68.3 \pm 16.6$ & $15.5 \pm 3.8$ \\
\hline
\end{tabular}

* The $\% \mathrm{CH}_{4}$ shown is the average value from Days 53-67 of the experiment. ${ }^{\#} \mathrm{The} \mathrm{CH}_{4}$ production from the inoculum was subtracted from all treatments, resulting in zero values when the inoculum outperformed the treatment.

As expected, the co-digestion treatments (with and without GVW addition) produced 359-524\% more $\mathrm{CH}_{4}$ compared to mono-DM digestion, when normalized by the mass of substrate added (Table 3 ). 
Normalized $\mathrm{CH}_{4}$ production in co-digestion without GVW (DM.FW.GW-only) was $11.6 \%$ lower than the 5\% GVW.DM.FW.GW mixture, 14.5\% lower than 9\% GVW.DM.FW.GW mixture, and 36.3\% lower than the $23 \%$ GVW.DM.FW.GW mixture (Table 3; Figure 1). The $\mathrm{CH}_{4}$ production in the $23 \%$ GVW.DM.FW.GW mixture was the highest among all treatments, as expected. The total normalized volume of $\mathrm{CH}_{4}$ increased linearly with the mass percent of GVW added $\left(\mathrm{r}^{2}=0.9866\right)$ (Figure 2).
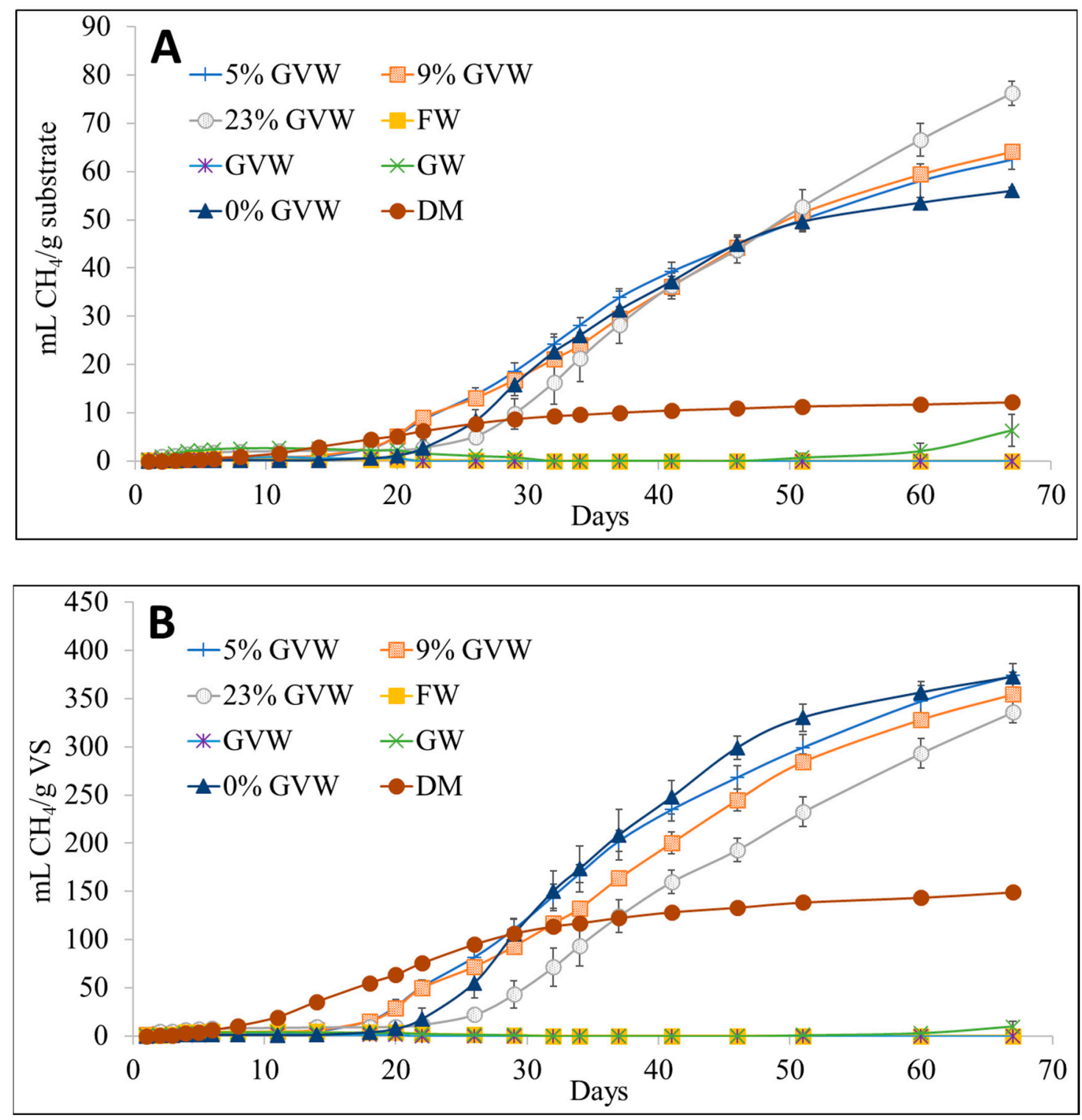

Figure 1. Methane $\left(\mathrm{CH}_{4}\right)$ production normalized by gram of substrate $\left(\mathrm{mL} \mathrm{CH}_{4} / \mathrm{g}\right.$ substrate) ((A), top) and by gram of volatile solids ( $\mathrm{mL} \mathrm{CH}_{4} / \mathrm{g}$ VS) $((\mathbf{B})$, bottom) in the batch digestion testing of gummy vitamin waste (GVW), grease waste $(\mathrm{GW})$, food waste (FW), and dairy manure (DM) digested singularly and as a mixture (DM.FW.GW), with the percent inclusion of GVW shown for the co-digestion mixtures.

When the total $\mathrm{CH}_{4}$ produced was normalized by the quantity of organic material added $\left(\mathrm{mL} \mathrm{CH}_{4} / \mathrm{g}\right.$ VS), the 23\% GVW.DM.FW.GW mixture was significantly lower than the DM.FW.GW mixture with $0 \%$ GVW $(p$-value $=0.0156)$ and 5\% GVW.DM.FW.GW mixtures $(p$-value $=0.0122)($ Table 3$)$, with no significant differences between the other co-digestion treatment groups. Mono-GVW digestion resulted in negligible $\mathrm{CH}_{4}$ production ( $0 \mathrm{~mL} \mathrm{CH}_{4} / \mathrm{g}$ VS) over 67 days of digestion due to subtraction of inoculum $\mathrm{CH}_{4}$ production from each treatment, and higher $\mathrm{CH}_{4}$ production values in the triplicate inoculum reactors 
compared to the triplicate GVW-only AD reactors. Both treatments with negligible $\mathrm{CH}_{4}$ production (mono-GVW and mono-FW) had low final pH levels in the digestion vessels (under $\mathrm{pH} 7$ ) (Table 4).

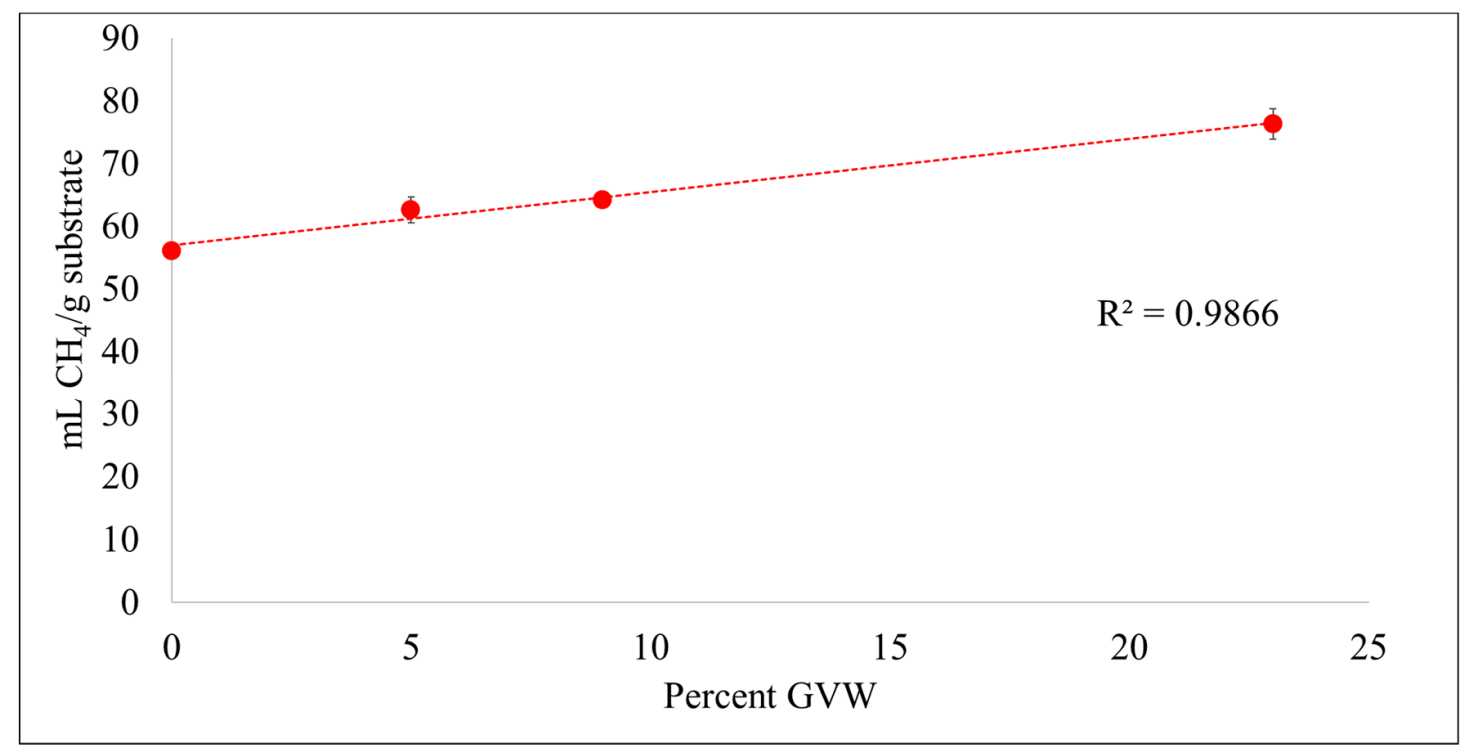

Figure 2. Linear regression of normalized methane $\left(\mathrm{CH}_{4}\right)$ production per gram of added substrate and percent gummy vitamin waste (GVW) within the co-digestion mixture.

Table 4. Average $\mathrm{pH}$ and volatile solids (VS) in all treatment mixtures pre-digestion (initial) and post-digestion (final). Initial VS data was calculated theoretically, and final VS data was determined experimentally.

\begin{tabular}{cccccc}
\hline Treatment & Initial VS (g/L) & Final VS (g/L) & Decrease in VS (\%) & Initial pH & Final pH \\
\hline Dairy manure (DM) & 59.5 & $48.0 \pm 1.8$ & $19.3 \%$ & 7.64 & 7.75 \\
Food waste (FW) & 60.0 & $42.0 \pm 2.5$ & $30.0 \%$ & 7.11 & 7.24 \\
Grease Waste (GW) & 87.5 & $79.5 \pm 1.1$ & $9.1 \%$ & 7.21 & 7.75 \\
Gummy vitamin waste (GVW) & 85.5 & $53.0 \pm 0.5$ & $38.0 \%$ & 7.92 & 7.97 \\
DM.FW.GW (0\% GVW) & 71.5 & $49.4 \pm 0.8$ & $30.9 \%$ & 7.84 & 7.87 \\
GVW.DM.FW.GW (5\% GVW) & 73.5 & $47.6 \pm 3.0$ & $35.2 \%$ & 7.95 \\
GVW.DM.FW.GW (9\% GVW) & 74.5 & $49.2 \pm 1.3$ & $34.0 \%$ & 7.77 \\
GVW.DM.FW.GW (23\% GVW) & 78.0 & $51.0 \pm 2.6$ & $34.6 \%$ & & 7.88 \\
\hline
\end{tabular}

\subsection{Hydrogen Sulfide $\left(\mathrm{H}_{2} \mathrm{~S}\right)$ Production}

The DM treatment produced biogas with a peak concentration of $2145 \mathrm{ppm} \mathrm{H}_{2} \mathrm{~S}$ after 3 days of digestion (Figure 3). After this time, $\mathrm{H}_{2} \mathrm{~S}$ levels decreased and no $\mathrm{H}_{2} \mathrm{~S}$ was detected in the biogas by the 60th day of the experiment. The treatment with the next highest peak $\mathrm{H}_{2} \mathrm{~S}$ concentration in the biogas was the $9 \%$ GVW.DM.FW.GW mixture (804 ppm $\mathrm{H}_{2} \mathrm{~S}$ ), which was $63 \%$ less than the DM treatment and 23\% greater than the next highest treatment (DM.FW.GW-only mixture with $0 \%$ GVW) at $576 \mathrm{ppm} \mathrm{H}_{2} \mathrm{~S}$. The peak $\mathrm{H}_{2} \mathrm{~S}$ concentrations for all treatments were observed within the first $2-3$ days before peak $\mathrm{CH}_{4}$ production. The $23 \%$ GVW.DM.FW.GW treatment, DM and FW had detectable $\mathrm{H}_{2} \mathrm{~S}$ concentrations in the biogas for the longest period (51 days). The mono-GVW treatment did not produce a measurable amount of $\mathrm{CH}_{4}$, but it had the shortest period of detectable levels of $\mathrm{H}_{2} \mathrm{~S}$ (5 days). This is likely due to lowered microbiological activity within the digester due to the low $\mathrm{pH}$ levels, which led to low biogas production. 


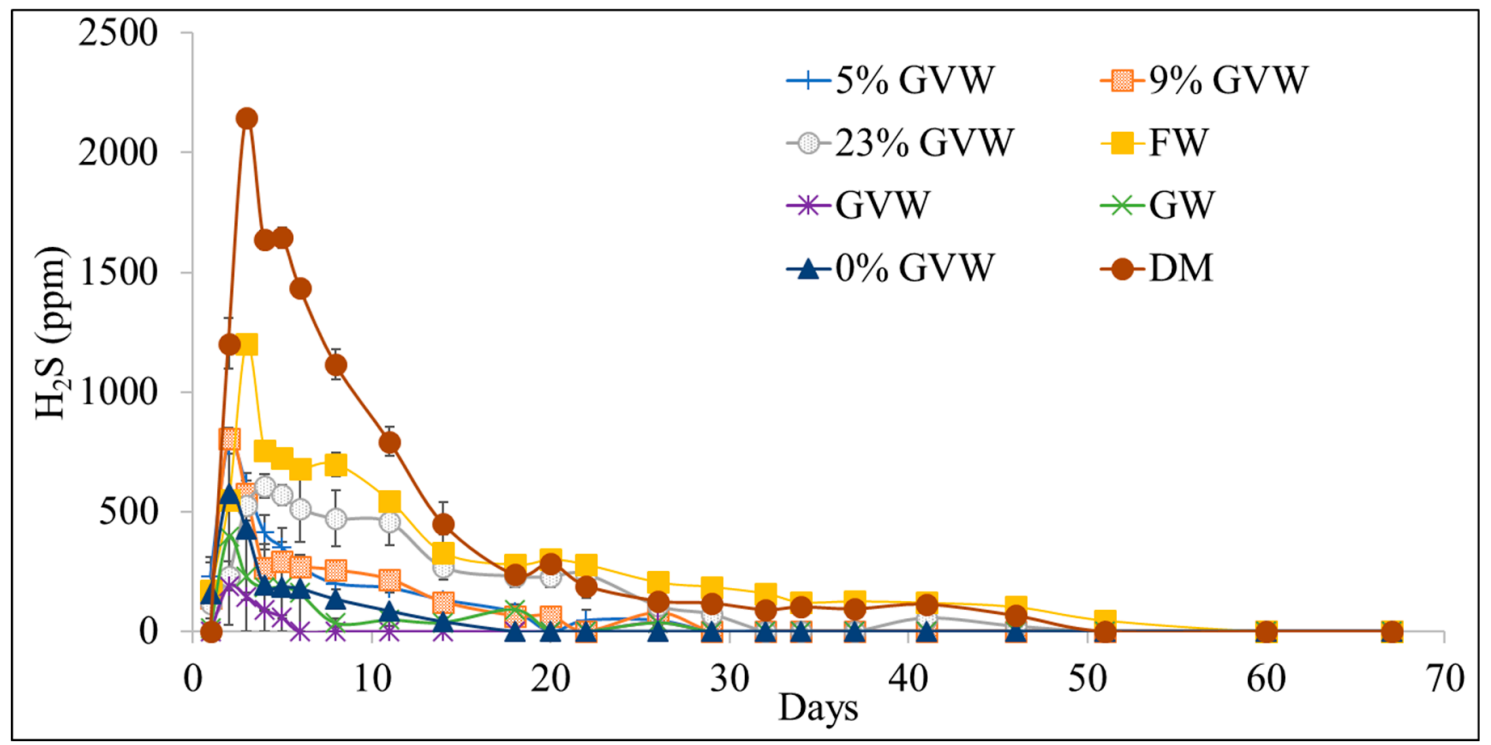

Figure 3. Hydrogen sulfide $\left(\mathrm{H}_{2} \mathrm{~S}\right)$ concentration $(\mathrm{ppm})$ in the biogas over time in the batch digestion testing of gummy vitamin waste (GVW), grease waste (GW), food waste (FW), and dairy manure (DM) digested singularly and as a mixture, with the GVW inclusion shown for each co-digestion mixture tested.

The quantity of $\mathrm{H}_{2} \mathrm{~S}$ produced showed an increasing trend with increases in the percent of GVW inclusion (0-23\%) when normalized by kilograms of substrate addition (5.3-15.5 $\mathrm{mL} \mathrm{H}_{2} \mathrm{~S} / \mathrm{kg}$ substrate; Table 3, Figure 4). The $\mathrm{H}_{2} \mathrm{~S}$ production in the DM treatment $\left(17.4 \mathrm{~mL} \mathrm{H}_{2} \mathrm{~S} / \mathrm{kg}\right.$ substrate) was significantly higher than the treatments co-digested with GVW ( $p$-value $=0.0046)$. However, in the DM.FW.GW treatment $(0 \% \mathrm{GVW})$, the normalized $\mathrm{H}_{2} \mathrm{~S}$ production was the lowest among the co-digested treatments (5.3 $\mathrm{mL} \mathrm{H}_{2} \mathrm{~S} / \mathrm{kg}$ substrate), and significantly lower than $23 \%$ GVW.DM.FW.GW ( $p$-value $=0.0106$ ) and $\mathrm{DM}$ ( $p$-value $=0.0023$ ) treatments. However, there were no significant differences for normalized $\mathrm{H}_{2} \mathrm{~S}$ production between the $5-23 \%$ GVW inclusion $(p$-value $=0.633)$ treatments.

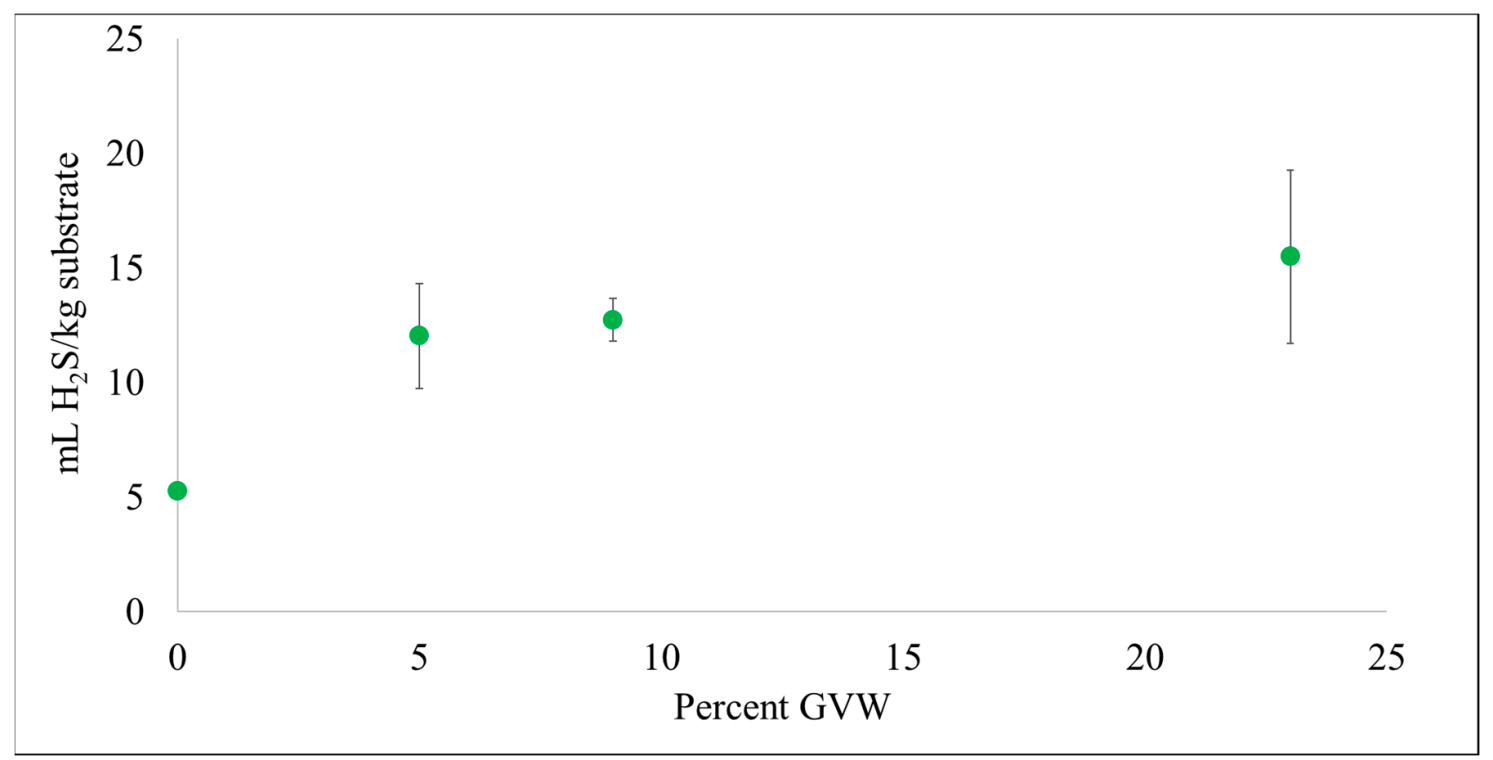

Figure 4. Normalized hydrogen sulfide $\left(\mathrm{H}_{2} \mathrm{~S}\right)$ production per kilogram of added substrate and percent gummy vitamin waste (GVW) within the co-digestion mixture. 
When the total $\mathrm{H}_{2} \mathrm{~S}$ was normalized by the amount of VS added, the DM treatment $(212 \mathrm{~mL}$ $\mathrm{H}_{2} \mathrm{~S} / \mathrm{kg}$ VS) produced a significantly larger amount of $\mathrm{H}_{2} \mathrm{~S}$ compared to all co-digestion treatments ( $p$-value $<0.0001)$ (Table 3). The addition of GVW $\left(68-72 \mathrm{~mL} \mathrm{H}_{2} \mathrm{~S} / \mathrm{kg}\right.$ VS) showed a significant increase in $\mathrm{H}_{2} \mathrm{~S}$ production compared to the DM.FW.GW ( $\left.0 \% \mathrm{GVW}\right)$ treatment $\left(35 \mathrm{~mL} \mathrm{H}_{2} \mathrm{~S} / \mathrm{kg}\right.$ VS; $p$-value $=0.0003$ ). However, there were no significant differences within the 5-23\% GVW.DM.FW.GW treatments $(p$-value $=1.000)$.

\subsection{Effect of Retention Time and Solids Degradation}

The percentage of $\mathrm{CH}_{4}$ in the biogas of the DM treatments rose above $25 \%$ on the 11 th day of digestion, while the treatments containing additional substrates (FW, GW, and GVW) had a longer lag phase and started producing higher quantities of $\mathrm{CH}_{4}$ after 20 days of digestion (Figure 1), which is a relatively long lag-time for BMP analyses. The DM treatment produced $43 \%$ of its total cumulative $\mathrm{CH}_{4}$ within the first 20 days, while all other treatments had less than $10 \%$ of the total cumulative $\mathrm{CH}_{4}$ production during this time (Table 5). By the 41 st day of the experiment, $89 \%$ of the total cumulative $\mathrm{CH}_{4}$ from the mono-DM treatment had been produced, but the percent of total cumulative $\mathrm{CH}_{4}$ from the GVW.DM.FW.GW and DM.FW.GW treatments by Day 41 varied from $57-80 \%$ of the cumulative $\mathrm{CH}_{4}$ after 67 days of digestion. The effect of the longer retention times on GVW degradation was seen, as the $\mathrm{CH}_{4}$ production rate for co-digestion was highest when no GVW was added (DM.FW.GW), with a maximum $\mathrm{CH}_{4}$ production rate of $16.8 \mathrm{~mL} \mathrm{CH}_{4} / \mathrm{VS}$.day). The maximum $\mathrm{CH}_{4}$ production rate decreased with increasing GVW inclusion (10.6-11.6 $\mathrm{mL} \mathrm{CH}_{4} / \mathrm{VS}$.day). The maximum $\mathrm{CH}_{4}$ production rate was the lowest for $\mathrm{DM}\left(6.0 \mathrm{~mL} \mathrm{CH} / \mathrm{VS}\right.$.day) for the treatments with $\mathrm{CH}_{4}$ generation.

Table 5. Normalized methane production ( $\mathrm{mL} \mathrm{CH}_{4} / \mathrm{g}$ VS) after 20, 46, and 67 days, with the percentage of the cumulative $\mathrm{CH}_{4}$ (Day 67) by Days 20 and 46 shown in parentheses.

\begin{tabular}{|c|c|c|c|}
\hline Treatment & $\begin{array}{c}\text { Day } 20 \\
\left(\mathrm{~mL} \mathrm{CH}_{4} / \mathrm{g} \mathrm{VS}\right)\end{array}$ & $\begin{array}{c}\text { Day } 46 \\
\left(\mathrm{~mL} \mathrm{CH}_{4} / \mathrm{g} \text { VS) }\right.\end{array}$ & $\begin{array}{c}\text { Day } 67 \\
\left(\mathrm{~mL} \mathrm{CH}_{4} / \mathrm{g} \mathrm{VS}\right) \\
\end{array}$ \\
\hline Dairy manure (DM) & $64(43 \%)$ & $133(89 \%)$ & 149 \\
\hline DM.FW.GW (0\% GVW) & $7(2 \%)$ & $299(80 \%)$ & 373 \\
\hline GVW.DM.FW.GW (5\% GVW) & $30(8 \%)$ & $268(72 \%)$ & 374 \\
\hline GVW.DM.FW.GW (9\% GVW) & $29(8 \%)$ & $245(69 \%)$ & 355 \\
\hline GVW.DM.FW.GW (23\% GVW) & $10(3 \%)$ & $193(57 \%)$ & 336 \\
\hline
\end{tabular}

The C:N ratios of the GVW (196:1) was high due to the high C (255 g C/kg GVW) and low N content (1.3 g N/kg GVW), which was much higher than the dairy manure (7.7:1) and inoculum (8.0:1) utilized. The TS and VS concentrations of the GVW showed that the VS comprised $99.7 \%$ of the total solids content ( $46.4 \%$ of the wet GVW). While a high percentage of the GVW was degradable, there was only a 34-35.2\% degradation of VS during digestion (Table 4). While there was no $\mathrm{CH}_{4}$ production from the mono-FW and mono-GW treatments, there was a decrease of $>30 \%$ of the initial VS content, which can be attributed to the initial breakdown of the organic matter, resulting in $\mathrm{CO}_{2}$-enriched biogas production. Biogas volume for these treatments was over $200 \mathrm{~mL}$ during the first two days, with less than $0.5 \% \mathrm{CH}_{4}$ and over $35 \% \mathrm{CO}_{2}$ for mono-FW and over $50 \% \mathrm{CO}_{2}$ for mono-GVW treatments.

\section{Discussion}

Increasing the amount of GVW during digestion did increase $\mathrm{CH}_{4}$ production, as expected. The GVW appeared to completely hydrolyze during digestion, with no visible trace of solid GVW in the post-BMP samples after 67 days of digestion. The GVW accounted for $5-23 \%$ of the total mass of substrate added, corresponding to $15-50 \%$ of the VS inclusion. The GVW product could be beneficial for farmers interested in co-digestion waste substrates that increase $\mathrm{CH}_{4}$ production, but the longer retention time of the GVW compared to DM digestion should be taken into consideration. 
The negligible $\mathrm{CH}_{4}$ production and low $\mathrm{pH}$ values in the mono-GVW, FW, and GW treatments compared to the higher $\mathrm{CH}_{4}$ production (336-374 $\mathrm{mL} \mathrm{CH}_{4} / \mathrm{g}$ VS) and $\mathrm{pH}$ range (7.88-7.95) in treatments that co-digested GVW, FW, GW, and DM showed that the buffering capacity of the added co-substrates is important to mitigate accumulation of volatile fatty acids (VFA) and lowered $\mathrm{pH}[3,21]$. Carbon-rich substrates can have a poor buffering capability, leading to an increased rate of VFA production and methanogenesis inhibition [3]. The mono-GW treatment had an initial pH of 7.79 but did not produce significant amounts of $\mathrm{CH}_{4}$, possibly due to the slow degradation rate of lipids in the grease waste. Previous studies have also shown that digestion of lipids without co-digestion required the use of lime as a $\mathrm{pH}$ stabilizer [22]. The use of a buffer for $\mathrm{pH}$ control in the experiment was avoided since the study was originally conducted to emulate the source farm conditions. The AD system on farm did not use any $\mathrm{pH}$ stabilizers, as the manure provided sufficient buffering capacity for the digestion process. Generally, the high alkalinity of manure increases digester resistance to acidification for high-fat and sugar content wastes and adds a nitrogen source for micro-organisms [23]. Another important parameter that likely resulted in negligible $\mathrm{CH}_{4}$ production in the mono-GVW treatment was the high C:N ratio of GVW (196:1). High C:N ratios have been shown to result in low $\mathrm{pH}$ values during the digestion process and high VFA production [24]. As DM had a C:N ratio of 7.7:1 in this study, which is typical for DM, the resulting mixture in the co-digestion treatments likely increased the $\mathrm{C}: \mathrm{N}$ ratio within the ideal range of 20-30 for $\mathrm{AD}$, resulting in large increases in $\mathrm{CH}_{4}$ yield for the co-digestion mixtures compared to the mono-digestion treatments [25].

All treatments produced large amounts of biogas during the first two days of digestion (ranging from $39 \mathrm{~mL}$ for DM to $379 \mathrm{~mL}$ for $23 \%$ GVW.DM.FW.GW), mostly composed of $\mathrm{CO}_{2}$. The biogas volume dropped sharply for all treatments ( $<10 \mathrm{~mL}$ per day) after Day 2, and the mono-DM treatment recovered the earliest (Day 11) and started producing $>50 \mathrm{~mL}$ biogas per day. The reduction in VS in the treatments with negligible $\mathrm{CH}_{4}$ production for FW, GVW, and GW (Table 4) can be attributed to this initial burst of $\mathrm{CO}_{2}$ enriched biogas production due to the initial breakdown of complex organic molecules. Bujoczek et al. (2000) showed that high organic loading rates may initially lead to large amounts of biogas, composed mainly of $\mathrm{CO}_{2}$, after which biogas production slows down [26]. In their study, the biogas production recovered after 30 days of digestion with $\mathrm{CH}_{4}$ as the main component, similar to the results seen in this experiment. The authors also reported that the highest TS content for feasibility of digestion was $10 \%$, while the shortest lag phase was obtained for $2.7 \%$ TS. The TS content in our experiment varied from $7.1 \%$ for DM to $11.6 \%$ for $\mathrm{FW}$ and showed similar $\mathrm{CH}_{4}$ production trends to their study. The longer lag phase associated with a high TS content could be due to either high VFA concentrations or high ammonia concentrations or a combination of the two factors [26]. The $\mathrm{CH}_{4}$ production in this study recovered after the lag phase, indicating acclimatization of the methanogenic bacteria to the initial inhibitory conditions, but the quantity of $\mathrm{CH}_{4}$ generated from the DM treatment $\left(149 \pm 11 \mathrm{~mL} \mathrm{CH}_{4} / \mathrm{g}\right.$ VS) was 38-44\% lower than the results obtained by Moody et al. (2011) for dairy manure (239-264 mL CH $4 / g$ VS) [6]. Witarsa and Lansing (2015) showed that the normalized $\mathrm{CH}_{4}$ production on a VS basis is often lower for unseparated dairy manure due to the recalcitrant nature of the manure solids, leading to lower VS conversion efficiency [27].

It was expected that $\mathrm{CH}_{4}$ production normalized by VS in the GVW co-digested treatments would be similar, but a decreasing trend with increasing percent GVW was observed. Normalization by VS illustrates the efficiency of organic material conversion to $\mathrm{CH}_{4}$. As GVW is a dense substrate in terms of grams of VS per gram of substrate, the increase in GVW inclusion decreased the efficiency and rate of converting the VS to $\mathrm{CH}_{4}$. The longer lag phase and the larger $\mathrm{CH}_{4}$ production rates in the GVW treatments compared to DM.FW.GW and DM-only, from Days 41 to 67 , suggests that long retention times would be needed to receive the full increase in expected $\mathrm{CH}_{4}$ production. This effect was also seen by Kaparaju et al. (2002) when black candy, chocolate, and confectionary by-products were digested with dairy manure for 160 days in order to obtain a complete cumulative $\mathrm{CH}_{4}$ value, with similar normalized $\mathrm{CH}_{4}$ production for the confectionary waste (320-390 $\mathrm{mL} \mathrm{CH}_{4} / \mathrm{g} \mathrm{VS}$ ) compared to the GVW.DM.FW.GW treatments (336-374 $\mathrm{mL} \mathrm{CH}_{4} / \mathrm{g}$ VS) [28]. 
In all treatments, the VS degradation was low compared to studies conducted by Lisboa and Lansing (2013) and Li et al. (2013), where the VS degradation rates ranged from 48-93\% [5,29]. Only $19.3 \%$ of the initial VS content of the mono-DM treatment was degraded at the end of the experiment, illustrating recalcitrance in the manure feed. The VS degradation was consistent with co-digestion studies of forage radish and dairy manure by Belle et al. (2015b), which used the same manure source as this study with a $21.3 \%$ reduction in VS concentration in the mono-DM treatment [30]. The VS degradation of our study (30.9-35.2\%) was also comparable to the aforementioned study (30.8-39.7\%), with 50-80\% co-digestion substrate with dairy manure.

In a review conducted by Xie et al. (2018), it was reported that addition of a carbon-rich substrate to sewage sludge digestion may lower the $\mathrm{H}_{2} \mathrm{~S}$ concentration due to a dilution effect [31]. This dilution effect can be attributed to a proportionally higher biogas yield compared to the additional $\mathrm{H}_{2} \mathrm{~S}$ produced from the co-digested substrates. The S concentration for GVW (212 ppm S) was lower than the inoculum source (368 ppm S), and unseparated dairy manure slurries with a TS content of $7 \%$ (average $400 \mathrm{ppm} \mathrm{S)} \mathrm{[32].} \mathrm{The} \mathrm{low} \mathrm{sulfur} \mathrm{concentrations} \mathrm{combined} \mathrm{with} \mathrm{the} \mathrm{high} \mathrm{VS} \mathrm{content} \mathrm{(46.3 \% )}$ of GVW, in comparison to DM ( $8.2 \% \mathrm{VS})$, provide more evidence to the dilution effect observed in the study, as previously hypothesized. Since more biogas was produced in the GVW treatments compared to the DM treatments, the relative percent of the biogas attributed to manure in the mixed substrate treatments was lowered, and thus, the relative contribution of $\mathrm{H}_{2} \mathrm{~S}$ from the manure substrate also decreased. Furthermore, the contribution of $\mathrm{H}_{2} \mathrm{~S}$ from GVW was comparatively lower due to its low sulfur content, leading to the overall decrease in $\mathrm{H}_{2} \mathrm{~S}$ concentrations in the biogas. However, it should be noted that the GVW addition as a co-digestion substrate increased total normalized $\mathrm{H}_{2} \mathrm{~S}$ production when compared to co-digestion with $0 \%$ GVW addition (DM.FW.GW). A co-digestion substrate with negligible $\mathrm{S}$ content could have led to further decreases in $\mathrm{H}_{2} \mathrm{~S}$ concentrations and total yield. Some gummy vitamins are fortified with $\mathrm{Fe}$, but the concentrations seen in this study ( $4.3 \mathrm{ppm} \mathrm{Fe}$ ) was lower than the Fe concentrations in food waste $(4800 \mathrm{ppm})$ and unlikely to have affected $\mathrm{H}_{2} \mathrm{~S}$ production in our study [33].

The sulfurous compounds in the feedstock were primarily utilized during the initial phase of digestion as most of the $\mathrm{H}_{2} \mathrm{~S}$ was produced within the first 20 days, after which the $\mathrm{CH}_{4}$ percentage started rising for all treatments. Similar results were also observed by Belle et al. (2015b) when co-digesting different mass fractions of forage radish with dairy manure in BMP experiments [30]. Forage radish has a high sulfur content and increasing the forage radish percentage led to an expected increase in $\mathrm{H}_{2} \mathrm{~S}$ production initially, but all the treatments had lowered and similar $\mathrm{H}_{2} \mathrm{~S}$ production by the end of the study. Belle et al. (2015a) also conducted a pilot-scale study on the same substrates and showed an increased rate of $\mathrm{H}_{2} \mathrm{~S}$ production during the first two weeks of digestion, after which, the concentration decreased by $>75 \%$ of the maximum $\mathrm{H}_{2} \mathrm{~S}$ concentration for the remainder of the digestion period (33 days total) [10]. These observations can be attributed to increased SRB activity during the initial digestion phase, as SRBs can outcompete methanogens when the availability of biodegradable sulfur is higher.

\section{Conclusions}

Results from the BMP study suggested that gummy waste is a potentially valuable co-digestion substrate with dairy manure. The mixture of substrates containing gummy waste, food waste, grease waste, and dairy manure enhanced $\mathrm{CH}_{4}$ yields compared to digestion of dairy manure alone. The high density of VS and low moisture content of the gummy waste results in high $\mathrm{CH}_{4}$ yields per gram of the substrate, but due to the slower degradation rate of the GVW, higher retention times may be needed to yield these higher $\mathrm{CH}_{4}$ potentials. Co-digestion of GVW with dairy manure lowered the $\mathrm{H}_{2} \mathrm{~S}$ yield and maximum $\mathrm{H}_{2} \mathrm{~S}$ concentration compared to mono-digestion of dairy manure due to its low sulfur content. The research highlighted the significance of testing co-digestion mixtures in conjunction with single substrates for both $\mathrm{CH}_{4}$ and $\mathrm{H}_{2} \mathrm{~S}$ to provide beneficial information for researchers and $\mathrm{AD}$ practitioners. Co-digestion of industrial byproducts and food waste mixtures in farm-scale biogas 
digesters could provide economic incentives for farmers through tipping fees and increased biogas production while redirecting valuable waste products from the landfills.

Author Contributions: Conceptualization, A.C. and S.L.; Data curation, A.C.; Formal analysis, A.C.; Funding acquisition, S.L.; Investigation, A.C.; Methodology, A.C. and S.L.; Project administration, S.L.; Resources, S.L.; Software, A.C.; Supervision, S.L.; Validation, A.C.; Visualization, S.L.; Writing-Original draft, A.C.; Writing-Review \& editing, A.C. and S.L.

Funding: This material is based upon work supported by the National Institute of Food and Agriculture at the U.S. Department of Agriculture through a Northeast Sustainable Agriculture Research and Education (SARE) grant (\# LNE15-341).

Acknowledgments: The authors would also like to thank the participating farmer for his enthusiasm and assistance with the project.

Conflicts of Interest: The authors declare no conflict of interest.

\section{References}

1. El-Mashad, H.M.; Zhang, R. Biogas production from co-digestion of dairy manure and food waste. Bioresour. Technol. 2010, 101, 4021-4028. [CrossRef] [PubMed]

2. Weiland, P. Biogas production: Current state and perspectives. Appl. Microbiol. Biotechnol. 2010, 85, 849-860. [CrossRef] [PubMed]

3. Mata-Alvarez, J.; Dosta, J.; Romero-Güiza, M.S.; Fonoll, X.; Peces, M.; Astals, S. A critical review on anaerobic co-digestion achievements between 2010 and 2013. Renew. Sustain. Energy Rev. 2014, 36, 412-427. [CrossRef]

4. Zhang, C.; Xiao, G.; Peng, L.; Su, H.; Tan, T. The anaerobic co-digestion of food waste and cattle manure. Bioresour. Technol. 2013, 129, 170-176. [CrossRef]

5. Lisboa, M.S.; Lansing, S. Characterizing food waste substrates for co-digestion through biochemical methane potential (BMP) experiments. Waste Manag. 2013, 33, 2664-2669. [CrossRef]

6. Moody, L.B.; Burns, R.T.; Bishop, G.; Sell, S.T.; Spajic, R. Using biochemical methane potential assays to aid in co-substrate selection for co-digestion. Appl. Eng. Agric. 2011, 27, 433-439. [CrossRef]

7. Braguglia, C.M.; Gallipoli, A.; Gianico, A.; Pagliaccia, P. Anaerobic bioconversion of food waste into energy: A critical review. Bioresour. Technol. 2018, 248, 37-56. [CrossRef]

8. Xu, F.; Li, Y.; Ge, X.; Yang, L.; Li, Y. Anaerobic digestion of food waste-Challenges and opportunities. Bioresour. Technol. 2018, 247, 1047-1058. [CrossRef]

9. Zhang, C.; Su, H.; Baeyens, J.; Tan, T. Reviewing the anaerobic digestion of food waste for biogas production. Renew. Sustain. Energy Rev. 2014, 38, 383-392. [CrossRef]

10. Belle, A.J.; Lansing, S.; Mulbry, W.; Weil, R.R. Anaerobic co-digestion of forage radish and dairy manure in complete mix digesters. Bioresour. Technol. 2015, 178, 230-237. [CrossRef]

11. Lupitskyy, R.; Alvarez-Fonseca, D.; Herde, Z.D.; Satyavolu, J. In-situ prevention of hydrogen sulfide formation during anaerobic digestion using zinc oxide nanowires. J. Environ. Chem. Eng. 2018, 6, 110-118. [CrossRef]

12. Pipatmanomai, S.; Kaewluan, S.; Vitidsant, T. Economic assessment of biogas-to-electricity generation system with $\mathrm{H} 2 \mathrm{~S}$ removal by activated carbon in small pig farm. Appl. Energy 2009, 86, 669-674. [CrossRef]

13. Corro, G.; Pal, U.; Bañuelos, F.; Rosas, M. Generation of biogas from coffee-pulp and cow-dung co-digestion: Infrared studies of postcombustion emissions. Energy Convers. Manag. 2013, 74, 471-481. [CrossRef]

14. RedCorn, R.; Fatemi, S.; Engelberth, A.S. Comparing End-Use Potential for Industrial Food-Waste Sources. Engineering 2018, 4, 371-380. [CrossRef]

15. Rusín, J.; Kašáková, K.; Chamrádová, K. Anaerobic digestion of waste wafer material from the confectionery production. Energy 2015, 85, 194-199. [CrossRef]

16. ASSOCIATED PRESS. Sweet news: Germany's Haribo to produce gummy bears in Wisconsin. Available online: https:/www.chicagotribune.com/business/ct-haribo-gummy-bear-factory-kenosha-wisconsin-20170324story.html (accessed on 17 November 2019).

17. Cecilia, J.A.; García-Sancho, C.; Maireles-Torres, P.J.; Luque, R. Industrial Food Waste Valorization: A General Overview. In Biorefinery; Springer: New York, NY, USA, 2019; pp. 253-277.

18. Delgado, P.; Bañón, S. Determining the minimum drying time of gummy confections based on their mechanical properties. CYTA - J. Food 2015, 13, 329-335. [CrossRef] 
19. Peters, J.; Combs, S.; Hoskins, B.; Jarman, J.; Kovar, J.; Watson, M.; Wolf, A.; Wolf, N. Recommended Methods of Manure Analysis; University of Wisconsin Cooperative Extension Publishing: Madison, WI, USA, 2003.

20. Adams, R.C.; Bennett, F.M.; Dixon, J.K.; Lough, R.C.; Maclean, F.S.; Martin, G.I. The utilization of organic wastes in NZ. New Zeal. Eng. 1951, 6, 396.

21. Lansing, S.; Martin, J.F.; Botero, R.B.; da Silva, T.N.; da Silva, E.D. Methane production in low-cost, unheated, plug-flow digesters treating swine manure and used cooking grease. Bioresour. Technol. 2010, 101, 4362-4370. [CrossRef]

22. Ugoji, E.O. Anaerobic digestion of palm oil mill effluent and its utilization as fertilizer for environmental protection. Renew. Energy 1997, 10, 291-294. [CrossRef]

23. Angelidaki, I.; Ahring, B.K. Codigestion of olive oil mill wastewaters with manure, household waste or sewage sludge. Biodegradation 1997, 8, 221-226. [CrossRef]

24. Wang, X.; Yang, G.; Feng, Y.; Ren, G.; Han, X. Optimizing feeding composition and carbon-nitrogen ratios for improved methane yield during anaerobic co-digestion of dairy, chicken manure and wheat straw. Bioresour. Technol. 2012, 120, 78-83. [CrossRef] [PubMed]

25. AgStar Increasing Anaerobic Digester Performance with Codigestion. Available online: http://www.epa.gov/ agstar/documents/codigestion.pdf (accessed on 17 November 2019).

26. Bujoczek, G.; Oleszkiewicz, J.; Sparling, R.; Cenkowski, S. High Solid Anaerobic Digestion of Chicken Manure. J. Agric. Eng. Res. 2000, 76, 51-60. [CrossRef]

27. Witarsa, F.; Lansing, S. Quantifying methane production from psychrophilic anaerobic digestion of separated and unseparated dairy manure. Ecol. Eng. 2015, 78, 95-100. [CrossRef]

28. Kaparaju, P.; Luostarinen, S.; Kalmari, E.; Kalmari, J.; Rintala, J. Co-digestion of energy crops and industrial confectionery by-products with cow manure: Batch scale and farm scale evaluation. Water Sci. Technol. 2002, 45, 275-280. [CrossRef]

29. Li, Y.; Zhang, R.; Liu, X.; Chen, C.; Xiao, X.; Feng, L.; He, Y.; Liu, G. Evaluating methane production from anaerobic mono- and co-digestion of kitchen waste, corn stover, and chicken manure. Energy and Fuels 2013, 27, 2085-2091. [CrossRef]

30. Belle, A.J.; Lansing, S.; Mulbry, W.; Weil, R.R. Methane and hydrogen sulfide production during co-digestion of forage radish and dairy manure. Biomass Bioenergy 2015, 80, 44-51. [CrossRef]

31. Xie, S.; Higgins, M.J.; Bustamante, H.; Galway, B.; Nghiem, L.D. Current status and perspectives on anaerobic co-digestion and associated downstream processes. Environ. Sci. Water Res. Technol. 2018, 4, 1759-1770. [CrossRef]

32. Chastain, J.P.; Camberato, J.J. Dairy manure production and nutrient content. In Confined Animal Manure Managers Certification Program Manual B Dairy Version 1; Clemson University Cooperative Extension Service, 2004; Volume 1, pp. 1-16. Available online: https://www.clemson.edu/extension/camm/manuals/dairy/ dch3a_04.pdf (accessed on 22 November 2019).

33. Tampio, E.; Ervasti, S.; Paavola, T.; Heaven, S.; Banks, C.; Rintala, J. Anaerobic digestion of autoclaved and untreated food waste. Waste Manag. 2014, 34, 370-377. [CrossRef]

(C) 2019 by the authors. Licensee MDPI, Basel, Switzerland. This article is an open access article distributed under the terms and conditions of the Creative Commons Attribution (CC BY) license (http://creativecommons.org/licenses/by/4.0/). 